University of Nebraska - Lincoln

DigitalCommons@University of Nebraska - Lincoln

USDA National Wildlife Research Center - Staff Publications
U.S. Department of Agriculture: Animal and Plant Health Inspection Service

2018

\title{
Environmental effects are stronger than human effects on mammalian predator-prey relationships in arid Australian ecosystems
}

\author{
Benjamin L. Allen \\ University of Southern Queensland, benjamin.allen@usq.edu.au \\ Alana Fawcett \\ University of the Sunshine Coast, alanafawcett@live.com.au \\ Alison Anker \\ Robert Wicks Pest Animal Research Centre \\ Richard M. Engeman \\ USDA-APHIS-Wildlife Services, s_r100@yahoo.com \\ Allan Lisle \\ USDA National Wildlife Research Center, alisle@uq.edu.au
}

See next page for additional authors

Follow this and additional works at: https://digitalcommons.unl.edu/icwdm_usdanwrc

Part of the Life Sciences Commons

Allen, Benjamin L.; Fawcett, Alana; Anker, Alison; Engeman, Richard M.; Lisle, Allan; and Leung, Luke K.-P., "Environmental effects are stronger than human effects on mammalian predator-prey relationships in arid Australian ecosystems" (2018). USDA National Wildlife Research Center - Staff Publications. 1989.

https://digitalcommons.unl.edu/icwdm_usdanwrc/1989

This Article is brought to you for free and open access by the U.S. Department of Agriculture: Animal and Plant Health Inspection Service at DigitalCommons@University of Nebraska - Lincoln. It has been accepted for inclusion in USDA National Wildlife Research Center - Staff Publications by an authorized administrator of DigitalCommons@University of Nebraska - Lincoln. 


\section{Authors}

Benjamin L. Allen, Alana Fawcett, Alison Anker, Richard M. Engeman, Allan Lisle, and Luke K.-P. Leung 


\title{
Environmental effects are stronger than human effects on mammalian predator-prey relationships in arid Australian ecosystems
}

\author{
Benjamin L. Allen ${ }^{\mathrm{a}, *}$, Alana Fawcett ${ }^{\mathrm{b}}$, Alison Anker ${ }^{\mathrm{c}}$, Richard M. Engeman ${ }^{\mathrm{d}}$, Allan Lisle ${ }^{\mathrm{e}}$, Luke K.-P. Leung ${ }^{\mathrm{e}}$ \\ a University of Southern Queensland, Institute for Agriculture and the Environment, Toowoomba, Queensland 4350, Australia \\ b University of the Sunshine Coast, Faculty of Science, Health, Education and Engineering, Sippy Downs, Queensland 4556, Australia \\ ${ }^{c}$ Robert Wicks Pest Animal Research Centre, Biosecurity Queensland, Department of Agriculture and Fisheries, Toowoomba, Queensland 4350, Australia

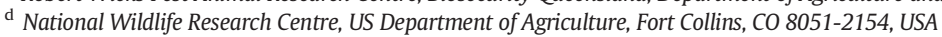 \\ e University of Queensland, School of Agriculture and Food Sciences, Gatton, Queensland 4343, Australia
}

\section{H I G H L I G H T S}

- Hopping-mice distribution was driven by geological factors, or habitat availability.

- Hopping-mice abundance was driven by climate, rainfall or food availability.

- Hopping-mice abundance and distribution fluctuates independent of predator control.

- Predator control is unlikely to increase hopping-mice distribution or abundance.

- Small mammals may benefit most from increased habitat and food availability

\section{A R T I C L E I N F O}

\section{Article history:}

Received 6 May 2017

Received in revised form 4 August 2017

Accepted 5 August 2017

Available online 14 September 2017

Editor: D. Barcelo

\section{Keywords:}

Apex predator

Climate change

Extinction risk

Food web

Species interactions

Trophic cascade

\section{GRA P H I C A L A B S T R A C T}

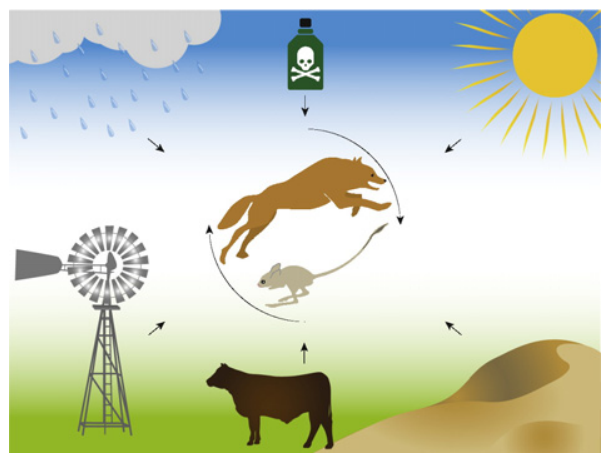

\section{A B S T R A C T}

Climate (drought, rainfall), geology (habitat availability), land use change (provision of artificial waterpoints, introduction of livestock), invasive species (competition, predation), and direct human intervention (lethal control of top-predators) have each been identified as processes driving the sustainability of threatened fauna populations. We used a systematic combination of empirical observational studies and experimental manipulations to comprehensively evaluate the effects of these process on a model endangered rodent, dusky hopping-mice (Notomys fuscus). We established a large manipulative experiment in arid Australia, and collected information from relative abundance indices, camera traps, GPS-collared dingoes (Canis familiaris) and dingo scats, along with a range of related environmental data (e.g. rainfall, habitat type, distance to artificial water etc.). We show that hopping-mice populations were most strongly influenced by geological and climatic effects of resource availability and rainfall, and not land use, invasive species, or human effects of livestock grazing, waterpoint provision, or the lethal control of dingoes. Hopping-mice distribution declined along a geological gradient of more to less available hopping-mice habitat (sand dunes), and their abundance was driven by rainfall. Hopping-mice populations fluctuated independent of livestock presence, artificial waterpoint availability or repeated lethal dingo control. Hopping-mice populations appear to be limited first by habitat availability, then by food availability, then by predation. Contemporary top-predator control practices (for protection of livestock) have little influence on hopping-mice behaviour or population dynamics. Given our inability to constrain the effects of predation across broad scales, management actions focusing on increasing available food and habitat (e.g. alteration of fire

\footnotetext{
* Corresponding author.

E-mail addresses: benjamin.allen@usq.edu.au (B.L. Allen), alanafawcett@live.com.au (A. Fawcett), Richard.M.Engeman@aphis.usda.gov (R.M. Engeman), alisle@uq.edu.au (A. Lisle), luke.leung@uq.edu.au (L.K.-P. Leung).
} 
and herbivory) may have a greater chance of improving the conservation status of hopping-mice and other small mammals in arid areas. Our study also reaffirms the importance of using systematic and experimental approaches to detect true drivers of population distribution and dynamics where multiple potential drivers operate simultaneously.

(c) 2017 Elsevier B.V. All rights reserved.

\section{Introduction}

Food web structure and stability in terrestrial systems are influenced by a myriad of biotic, abiotic, and anthropogenic factors (Kershaw, 1969; Krebs, 2008). Commonly discussed factors include climate change, land use change, deforestation and invasive species (e.g. Petchey et al., 1999; Kinnaird et al., 2003; Tylianakis et al., 2008; Sinclair et al., 2013). While the effects of bottom-up factors (e.g. geology or habitat, climate or rainfall) on subsequent population growth within flora and fauna communities may be readily understandable (Robin et al., 2009; White, 2013), a growing body of research points to the effects that top-predators can have in shaping food web structure and stabilising the influence of other factors (Estes et al., 2013; Ripple et al., 2014). Through their suppressive effects on mesopredators and prey, top-predators might provide indirect benefits to some prey and vegetation at lower trophic levels, thereby maintaining ecosystem health and resilience. The strength of such trophic cascades is dependent on the complexity of the system and the number of trophic levels represented (Finke and Denno, 2004; Holt and Huxel, 2007), with toppredators typically exhibiting stronger effects in simpler systems with fewer trophic levels. These findings have led some to suggest that the maintenance, restoration or encouragement of top-predators is essential for the recovery of threatened fauna populations, communities and ecosystems (Ritchie et al., 2012; Ripple et al., 2014). However, there is also a large and growing body of evidence that these expectations are often not realised in situ given highly context-dependent factors and the complexities of even 'simple' systems (Sergio et al., 2008; Allen et al., 2014a; Haswell et al., 2017), especially those modified by humans (Linnell, 2011; Fleming et al., 2012; Wikenros et al., 2015). Understanding the relative influence of top-down and bottom-up factors on ecosystems remains a key priority for managers of predators and threatened fauna.

The complete removal of top-predators can have profound effects on ecosystem health and resilience (Estes et al., 2011), but whether or not their restoration can reverse these effects and restore ecosystems to previous benchmarks is less clear (e.g. Marshall et al., 2013). Moreover, whether or not the temporary suppression of common and widespread top-predators causes the same effects as complete predator removal is even less certain (Fleming et al., 2012; Allen et al., 2014a). Bottom-up factors, such as habitat availability, fire, rainfall or drought, are the primary drivers of fauna populations (White, 2013; Lawes et al., 2015). Top-down and bottom-up processes occur simultaneously, and also interact. For example, climate change may foster increased predation of prey fauna reliant on vegetation for food and refuge by increasing the frequency and severity of rainfall and subsequent vegetation shortages (Whetton et al., 1993; Letnic and Dickman, 2010). Such effects of climate change may be particularly important for irruptive or 'boom and bust' prey species, typical of desert biota, by extending the period that prey are exposed to high levels of predation (Newsome et al., 1989; Allen and Fleming, 2012). Extended periods of drought are known to exacerbate predation risks to irruptive fauna that typically persist in isolated and low-density populations (e.g. Dickman et al., 1999; Letnic and Dickman, 2006). However, there remains a dearth of studies demonstrating these expected functional relationships for many threatened fauna persisting in desert ecosystems, and identifying the strongest factors influencing prey populations has proved difficult (Holmes, 1995; Marshall et al., 2014; Peterson et al., 2014). All components of food webs interact to some extent (Allen et al., 2017), but few interactions are strong enough to shape them. Although general ecological patterns may already be apparent, the outcomes of global environmental change are highly unpredictable, and 'the greatest single challenge will be to determine how context alters the direction and magnitude of effects on biotic interactions' (Tylianakis et al., 2008).

In this study, we investigate the influence of multiple biotic and abiotic factors affecting predator-prey relationships in the arid Strzelecki Desert region of central Australia. The Strzelecki Desert is characterized by a depauperate mammal assemblage comprised of one top-predator (dingoes, Canis familiaris), two mesopredators (European red foxes, Vulpes vulpes, and feral cats, Felis catus) and two common mammalian prey species, European rabbits (Oryctolagus cuniculus) and dusky hopping-mice (Notomys fuscus; hereafter hopping-mice). Other predator and prey species are present (Van Dyck and Strahan, 2008), but persist in variable or low densities that likely have relatively minimal influence on these mammals (Allen et al., 2014a). Beef-cattle grazing is the primary land use in this region (Allen, 2015a). Dingoes, foxes, cats and rabbits were each introduced to Australia. Dingoes arrived approximately 5000 years ago, whereas foxes, cats and rabbits were introduced soon after European colonisation in the late 1700s (Johnson, 2006); each are widespread and common (West, 2008). All three predators are relatively small ( $<16 \mathrm{~kg}$ mean adult body weight), generalist carnivores with highly overlapping diets primarily consisting of medium and small-sized mammals (e.g. Pavey et al., 2008; Cupples et al., 2011; Glen et al., 2011; Allen and Leung, 2012). Hopping-mice are native and endemic to Australia. Their range has declined by over $90 \%$ since the arrival of Europeans and the subsequent ecological changes associated with the introduction of livestock and invasive species (e.g. foxes, cats and rabbits). The Strzelecki Desert is the last stronghold of hopping-mice (Lee, 1995; Moseby et al., 1999; Van Dyck and Strahan, 2008), which are an endangered, 'old world' or conilurine rodent (Muridae) with irruptive population cycles typical of many small mammals in arid areas.

Previous desktop, snap-shot and correlative studies (compiled and reviewed in Allen et al., 2013b) have developed the following hypotheses about the contemporary relationships between dingoes and hopping-mice in this study system:

1. Dingo abundance is positively correlated with hopping-mice abundance (presumably because dingoes provide indirect refuge to hopping-mice from mesopredators).

2. The presence of dingoes positively affects hopping-mice foraging behaviour (presumably because hopping-mice perceive foraging in the presence of dingoes to be less of a risk than foraging in their absence).

3. The lower abundance of hopping-mice in the east of the Strzelecki Desert is due to the relative absence of dingoes there (which are excluded by the dingo barrier fence).

4. Contemporary dingo control practices (i.e. repeated broad-scale poison-baiting, undertaken to protect cattle from dingo predation) reduces the abundance of dingoes, and increases the abundance of mesopredators, which reduces the abundance of hopping-mice.

5. Dingoes do not eat hopping-mice in quantities sufficient to threaten the persistence of hopping-mice populations.

Alternative hypotheses for these observations have seldom been assessed, however, and limited experimental work has been undertaken to identify causal relationships driving the observed correlations between dingoes and hopping-mice (Allen, 2011a; Allen et al., 2013b; 
Table 1

Summary of previously published empirical research studies from the experiment conducted at Quinyambie between April 2008 and February 2012.

\begin{tabular}{|c|c|c|}
\hline Reference & Subject & Key finding(s) \\
\hline Allen, 2010 & Dingo scavenging during drought & - Dingoes scavenge a wide variety of food items during chronic drought \\
\hline Allen et al., 2011 & Records of rarely-seen small mammals in dingo scats & $\begin{array}{l}\text { Dusky hopping-mice, plains mice and long-haired rats are present at } \\
\text { Quinyambie and some other sites in northern South Australia }\end{array}$ \\
\hline Allen and Leung, 2012 & Assessing dingo predation risk to rodents & $\begin{array}{l}\text { - Rodents are common prey for dingoes } \\
\text { - Predation risk to rodents may be severe in certain contexts } \\
\text { - Scat data alone are insufficient for determining predation risk }\end{array}$ \\
\hline Allen, 2012a & Usage of waterpoints by dingoes & $\begin{array}{l}\text { - Dingoes visit waterpoints once every few days, on average } \\
\text { - Dingoes can go up to } 22 \text { days without drinking free water } \\
\text { - Waterpoints are shared by several different dingo packs }\end{array}$ \\
\hline Allen, 2012b & $\begin{array}{l}\text { Responses of dingoes to broad-scale poison-baiting } \\
\text { and shooting }\end{array}$ & $\begin{array}{l}\text { - Dingo populations are resilient to contemporary lethal control practices } \\
\text { - Dingo control may facilitate increased rates of hybridisation }\end{array}$ \\
\hline Allen, 2012c & Variability in dingo scat collection rates & - Dingo scat collection rates vary spatially and temporally \\
\hline Allen et al., 2013a & $\begin{array}{l}\text { Relationships between sympatric predators exposed } \\
\text { to lethal dingo control }\end{array}$ & $\begin{array}{l}\text { - Relationships between dingoes and mesopredators are typically neutral } \\
\text { or positive over time, and independent of baiting }\end{array}$ \\
\hline Allen et al., 2014a & $\begin{array}{l}\text { Responses of sympatric predators and prey to lethal } \\
\text { dingo control }\end{array}$ & $\begin{array}{l}\text { - Baiting does not reduce dingo populations to levels low enough for long enough } \\
\text { to generate positive responses from mesopredators } \\
\text { - Both predator and prey trends fluctuate independent of baiting in almost all } \\
\text { cases (i.e. no mesopredator release or prey suppression in response to baiting) }\end{array}$ \\
\hline Allen et al., 2014b & $\begin{array}{l}\text { Effects of lethal dingo control on dingo movements } \\
\text { and detectability }\end{array}$ & $\begin{array}{l}\text { - Dingo movement behaviours do not change in response to baiting } \\
\text { - Changes in dingo activity following baiting are more likely to represent } \\
\text { numerical declines and not behavioural responses }\end{array}$ \\
\hline Allen and Leung, 2014 & $\begin{array}{l}\text { Effects of lethal dingo control on dingo diet and } \\
\text { prey selection }\end{array}$ & $\begin{array}{l}\text { - Dingo dietary diversity and similarity are identical or near-identical } \\
\text { between baited and unbaited areas }\end{array}$ \\
\hline
\end{tabular}

Newsome et al., 2015). Previous studies have investigated these hypotheses by undertaking snap-shot or single survey studies, collecting meagre amounts of empirical data, followed by extensive and complex post hoc modelling to try and elucidate causal mechanisms from correlative data (e.g. Moseby et al., 2006; Letnic et al., 2009; Letnic and Koch, 2010; Gordon et al., 2015; Gordon et al., 2017). In contrast to this approach, we focus on obtaining high-quality empirical data capable of addressing the above hypotheses directly. We use a variety of complimentary techniques on a variety of data obtained as part of a large-scale manipulative experiment investigating the effects of lethal dingo control on dingo abundance and ecological function (Eldridge et al., 2016). Our primary aim was to characterise the nature of the relationship between dingoes and hopping-mice by testing the five aforementioned hypotheses through assessment of 13 interrelated study questions within three relationship categories.

\section{Methods}

\subsection{Data sources}

We conducted a systematic and complimentary series of empirical studies against a background of a large-scale and long-term manipulative experiment on dingo ecology and management in northern South Australia, conducted between April 2008 and February 2012. A series of reports based on this experiment have already been published (Table 1; see also Eldridge et al., 2016). Hence here, we focus the present investigation on the behavioural, numerical, spatial, and predatory aspects of the relationship between dingoes and hopping-mice with data drawn from the results of these published and additional unpublished data from the experiment. General description of our methods is provided in Sections 2.2-2.7, with additional methodological detail available in the supplementary material, and also the Methods sections of the reports listed in Table 1. Not all data collection techniques described below were undertaken simultaneously, or were necessary for addressing each study question. Thus, our approach was to draw on as much available empirical data as was relevant for answering each individual question.

\subsection{Study site}

The study was conducted in the sandy and arid Strzelecki Desert of northeastern South Australia (NSA), within $100 \mathrm{~km}$ radius of $30^{\circ} 31^{\prime}$ $33.45^{\prime \prime} \mathrm{S}, 140^{\circ} 39^{\prime} 37.72^{\prime \prime} \mathrm{E}$. The study site is part of Quinyambie Station, a $12,000 \mathrm{~km}^{2}$ beef-cattle producing property where vegetation is dominated by low-growing hopbush (Dodonaea viscosa), buckbush (Salsola kali) and a variety of grasses and burrs including kerosene grass (Aristida spp.) and copperburr (Sclerolaena spp.) (Plate S1; Kutsche and Lay, 2003). Landform is comprised of parallel sand dunes and clay swales, which are generally aligned east-west (Plate S1; Fitzsimmons, 2007). The area is one of the hottest and driest regions of Australia. Summertime temperatures can exceed $50^{\circ}$ Celsius, and the area has a mean annual rainfall of $\sim 160 \mathrm{~mm}$, which is highly variable (Fig. S1; www.bom.gov.au). There are no natural and permanent surface water sources at the site. Rather, viable livestock production is made possible only through the provisioning of artificial water drawing from artesian and sub-artesian sources (Fensham and Fairfax, 2008; Allen, 2011a). Rainfall conditions in the area had been below-average for several years prior to the commencement of the study in March 2008, and were extremely dry by September 2009 (Plate S1, Fig. S1). Approximately 30-40 dust storms occurred at the site in the latter half of 2009 , removing $10-50 \mathrm{~cm}$ of sand from dunes, destroying their surface structure and removing food and shelter for small mammals and other herbivores (Allen, 2010). Similar effects were apparent in swales. Record-breaking rains began falling in November 2009, which marked the beginning of a 36 month period of above-average or near-average monthly rainfall (Fig. S1). The five-year study period therefore encompassed both extreme drought (2008-2009) and extreme flush conditions (2010 - 2012) (Plate S1).

\subsection{Study design}

Lethal control of dingoes occurs sporadically across NSA to mitigate cattle predation by dingoes. Contemporary lethal control practices are characterized by spatiotemporally variable distribution of relatively minor amounts of meat bait poisoned with sodium fluoroacetate (or '1080'), which occurs up to twice annually in some parts of the Strzelecki Desert, with negligible long-term effect on dingo abundance or function (Allen, 2012b; Allen et al., 2013a). No baiting had occurred in the study area for many years prior to the study, but was previously exposed to opportunistic shooting of dingoes only. Therefore, we randomly established two sub-sites - one baited area (Finlay, $1500 \mathrm{~km}^{2}$ ) and one adjacent unbaited reference area (Coonee, $3000 \mathrm{~km}^{2}$ ) - in order to investigate in situ predator-prey relationships in places with and without lethal dingo control. Maps of the study site can be found 
in the studies listed in Table 1 (but for detail, see Eldridge et al., 2016). A $50 \mathrm{~km}$ transect was established along unformed vehicle tracks within each treatment to monitor animal activity. A buffer zone was established between the treatments, where transects were separated by $>20 \mathrm{~km}$ at their closest point to maintain treatment independence during any given animal activity survey. This distance was the width of approximately 3-5 dingo home ranges at the site (Allen, 2012a; Allen et al., 2014b). A graphical description of the experimental design is provided in Allen et al. (2013a). The primary purpose of the larger experiment was to investigate the effects of dingoes and lethal dingo control (i.e. baiting) on livestock and other wildlife at the site, after accounting for multiple other factors.

\subsection{Passive tracking indices}

The relative abundances of dingoes, hopping-mice and other wildlife were assessed using passive tracking indices (PTI; Engeman and Allen, 2000; Allen et al., 2014a), a non-invasive survey technique used in many parts of the world to simultaneously monitor populations of a variety of ground-dwelling vertebrates (e.g. Engeman and Evangelista, 2006; Blaum et al., 2008; Claridge et al., 2010). Almost all studies addressing the ecological roles of dingoes in Australian ecosystems have used this fauna sampling technique (Allen et al., 2013b), for which a great deal of methodological development and validation has been undertaken (Engeman et al., 1998; Engeman, 2005; Allen and Engeman, 2014). Track intrusions (or footprints) for each species in each $24 \mathrm{~h}$ period were counted on 50 sand plot tracking stations spaced $1 \mathrm{~km}$ apart on each transect (100 sand plots in total). The location of the first sand plot in each treatment was randomly selected. Sand plot tracking stations consisted of a $\sim 120 \mathrm{~cm}$ wide swathe of smoothed sand which spanned the road (Plate S2). Sand plots were read and refreshed at the same time daily for up to three consecutive days by the same experienced observer during each survey. A small mark was placed on each sand plot and checked the next day to ensure all plots were readable. Plots rendered unreadable by wind or rain were excluded. All wildlife track intrusions on sand plots were recorded. However, the number of hopping-mice tracks recorded on any given sand plot on any given day was limited to 15 , which represented saturation of the sand plot with hopping-mice tracks. Tracks of dingoes and most other wildlife could still be observed when the sand plot was saturated with hopping-mice tracks because dingoes $(\sim 16 \mathrm{~kg}$; Table $\mathrm{S} 1$, see also Allen and Leung, 2014) are much heavier than hopping-mice ( $35 \mathrm{~g})$ and left depressions in the sand which were unlikely to be erased by hopping-mice activity. For each sand plot, we recorded the distance to the closest water point and whether or not the sand plot was located on a dune or in a swale. Results from PTI calculations are expressed as the number of animal tracks per sand plot tracking station per $24 \mathrm{~h}$ period (or the mean of daily means; Allen et al., 1996). Tracking plot surveys were conducted quarterly and at the same time each year, although excessive wind or rain prohibited undertaking some surveys. Sampling fauna in this way allows PTI calculations to be used as a reliable measure of activity or relative abundance when analysed appropriately (Wilson and Delahay, 2001; Engeman, 2005; Allen and Engeman, 2014; but see Hayward and Marlow, 2014, Nimmo et al., 2015 and Hayward et al., 2015 for further discussion).

\subsection{Camera trapping}

We placed a total of 30 Reconyx ${ }^{\circledR}$ rapidfire cameras along both transects (20 in Finlay and 10 in Coonee) for 27 consecutive days between the 10th June and 11th July 2011 to assess the behaviour and timing of hopping-mice activity, which was expected to occur between dusk and dawn. Sunrise and sunset times at Broken Hill (130 km southeast of the study site) on the 21st June 2011 were 07:04 and 17:07 (www. ga.gov.au). Cameras were positioned on a steel post $\sim 30 \mathrm{~cm}$ off the ground at a $45^{\circ}$ angle to the road and facing a sand plot tracking station
(Plate S2; Allen, 2011b). This camera type was chosen over others for its greater ability to detect small mammals (Meek et al., 2012; Meek and Pittet, 2012). All cameras remained fully operational for the duration of their deployment. No attempts were made to discriminate between individual animals of the same species in sequential photos.

\subsection{GPS collaring of dingoes}

The movement behaviour and timing of dingo activity was assessed by monitoring dingoes with GPS tracking collars. Dingoes of mixed ages and both sexes from 10 separate packs (four in Coonee and six in Finlay) were trapped, collared and then released in two separate events (Allen, 2011b, 2012a). Eleven dingoes were captured at two waterpoints with soft-catch 'Jake' traps during the nights of the 11th and 12th November 2008 in Coonee, and an additional 13 dingoes were similarly captured on the nights of the 4th and 5th May 2011 in Finlay (Table S1). Dingoes were fitted with $\sim 450 \mathrm{~g}$ datalogging ARGOS-linked GPS tracking collars (Sirtrack Ltd., New Zealand) programmed to record a GPS point each 30 min continuously. Some collared dingoes died, slipped the collar off or could not be located subsequently, resulting in data from only 17 dingoes being available for our analyses. Positional accuracy was assessed using Horizontal Dilution of Precision (HDOP) values recorded with each GPS point, where a HDOP of 0 indicates excellent accuracy ( 2-4 $\mathrm{m}$ on-ground error) and a HDOP of 15 is indicative of poorer accuracy. Fixed or stationary collar tests and ground-truthing revealed that HDOP values of $\leq 3$ represented $<20$ m error on the ground while values of 15 represented $<50 \mathrm{~m}$ error (e.g. Allen et al., 2014b). Both were considered acceptable, and with $>96 \%$ of GPS points having a HDOP $\leq 3$, we did not exclude any GPS points based on HDOP values.

\subsection{Dingo diet and prey selection}

The diet of dingoes within each treatment was assessed by systematically collecting dingo scats from within $100 \mathrm{~m}$ of five randomly selected artificial waterpoints during each survey (two in Coonee and three in Finlay; for additional description, see Allen, 2012c; Allen and Leung, 2012; Allen and Leung, 2014). Scats were washed and analysed by a professional service provider who identified the food items present in the scats to the lowest taxonomic level possible using diagnostic characteristics of mammalian hair (Brunner and Coman, 1974; Brunner et al., 2002). Results were reported at the genus level (or higher) where there was ambiguity over positive species-level identification. Non-mammal food items were categorised simply as birds, reptiles (inclusive of both smooth- and rough-scaled species, such as scincidae or agamidae), invertebrates or vegetation; these were only described to the species level opportunistically (by staff at the South Australian museum) according to the incidental presence of diagnostic bones and other features in the scat (such as teeth or scales). Where multiple species were identified in a single scat, they were listed in order of volume. Results are expressed as the percent occurrence of a given species in scats at a given survey, which is best suited for studies (such as ours) that describe diets where most items occur relatively infrequently (Klare et al., 2011).

\section{Results}

Primary results are presented in Sections 3.1-3.3 and summarised in Table 2, with additional detail available in the supplementary material.

\subsection{Behavioural relationships between dingoes and hopping-mice}

Hopping-mice first appeared on camera just after sunset at 17:21, were active throughout the night (Plate S3), and were last observed just before dawn at 06:33 (Fig. S2). Dingoes exhibited a more crepuscular pattern of activity on camera, peaking just before dawn. Expressed as ' $\mathrm{N}$ animals per camera', there was no linear relationship $(\mathrm{r}=-0.2860$, 
Table 2

Relationships and study questions assessed, and general description of methods, available data and results (additional description of methods and results is available in the supplementary material).

\begin{tabular}{|c|c|c|c|c|}
\hline Relationship type & Study question & Methods & Available data & Results \\
\hline \multirow[t]{4}{*}{ Behavioural relationships } & $\begin{array}{l}\text { Do hopping-mice behave differently at times when } \\
\text { dingoes are active or less-active? }\end{array}$ & $\begin{array}{l}\text { Camera traps }(\mathrm{N}=10) \text { monitoring } \\
\text { between } 10 \text { th June and } 11 \text { th July } 2011\end{array}$ & $\begin{array}{l}2660 \text { photos, } 272 \text { of which show hopping-mice } \\
\text { behaviour in hours when dingoes were active } \\
\text { or less-active }\end{array}$ & $\begin{array}{l}\text { Hopping-mice are nocturnal (first detected just after } \\
\text { sunset at 17:21 and last seen } ~ 30 \text { mins before dawn at } \\
06: 33 \text { ) } \\
\text { Hopping-mice exhibit similar behaviours in hours } \\
\text { when dingoes are present or not }\end{array}$ \\
\hline & $\begin{array}{l}\text { Do dingoes select sand dunes (preferred } \\
\text { hopping-mice habitat) over swales? }\end{array}$ & $\begin{array}{l}\text { GPS tracking data collected each } 30 \text { mins } \\
\text { continuously from dingoes captured and }\end{array}$ & $\begin{array}{l}112,816 \text { GPS points from } 16 \text { collared dingoes } \\
\text { that used dune and swale habitats }\end{array}$ & Dingoes preferentially select dunes over swales \\
\hline & $\begin{array}{l}\text { Are dingoes active on dunes during the times } \\
\text { when hopping-mice are also active? }\end{array}$ & $\begin{array}{l}\text { collared in dingo-baited and unbaited areas } \\
\text { between 11th November } 2008 \text { and 23rd } \\
\text { February } 2012\end{array}$ & $\begin{array}{l}\text { Timing of } 112,816 \text { GPS points from } 16 \text { collared } \\
\text { dingoes on dunes during night-time hours when } \\
\text { hopping-mice are active }\end{array}$ & $\begin{array}{l}\text { Dingoes are active on dunes when hopping-mice are } \\
\text { also active on dunes }\end{array}$ \\
\hline & What is the density of dingoes? & & $\begin{array}{l}\text { Demographic data on } 24 \text { captured dingoes, and } \\
\text { opportunistic observations of group size and } \\
\text { reproductive output collected during the study }\end{array}$ & $\begin{array}{l}\text { Dingo densities }=0.4 / \mathrm{km}^{2} \text { (or } \sim 10 \text { dingoes in a typica } \\
5 \mathrm{~km} \times 5 \mathrm{~km} \text { home range area) }\end{array}$ \\
\hline \multirow[t]{5}{*}{$\begin{array}{l}\text { Spatial and numerical } \\
\text { relationships }\end{array}$} & $\begin{array}{l}\text { Is hopping-mice activity greater on dunes or } \\
\text { swales? }\end{array}$ & $\begin{array}{l}\text { Passive Tracking Indices (PTI) from sand } \\
\text { plots in dingo-baited }(\mathrm{N}=50 \text { plots) and } \\
\text { unbaited }(\mathrm{N}=50 \text { plots }) \text { areas collected }\end{array}$ & $\begin{array}{l}\text { Hopping-mice PTI values for each survey on } \\
\text { dunes and swales }\end{array}$ & $\begin{array}{l}\text { Hopping-mice PTI is much greater on dunes than it is } \\
\text { on swales, in times of both boom and bust (flush and } \\
\text { drought) in both baited and unbaited areas }\end{array}$ \\
\hline & $\begin{array}{l}\text { Are temporal trends in dingo and hopping-mice } \\
\text { PTI similar between dingo-baited and unbaited } \\
\text { areas, and is this result dependent on sampling in } \\
\text { dunes or swales? }\end{array}$ & $\begin{array}{l}\text { systematically during } 16 \text { surveys between } \\
\text { April } 2008 \text { and May } 2012\end{array}$ & $\begin{array}{l}\text { Dingo and hopping-mice PTI trends measured } \\
\text { on dunes and swales in both dingo-baited and } \\
\text { unbaited areas }\end{array}$ & $\begin{array}{l}\text { Both dingo and hopping-mice PTI trends are } \\
\text { near-identical between baited and unbaited areas, } \\
\text { regardless of whether or not sampling occurs on dunes } \\
\text { or swales }\end{array}$ \\
\hline & $\begin{array}{l}\text { In areas where dingoes are unbaited, are dingo and } \\
\text { hopping-mice PTI levels consistent across the } \\
\text { environmental gradient extending from the centre } \\
\text { of the desert towards the edge of the desert, and is } \\
\text { this result dependent on sampling in dunes or } \\
\text { swales? }\end{array}$ & & $\begin{array}{l}\text { Dingo and hopping-mice PTI values measured } \\
\text { on dunes }(\mathrm{N}=24) \text { and swales }(\mathrm{N}=26) \text { along } \\
\text { transects that run in either a north-south } \\
\text { (remaining in the centre of the desert) or } \\
\text { west-east (from the centre of the desert towards } \\
\text { the edge) direction, in unbaited areas only }\end{array}$ & $\begin{array}{l}\text { Both dingo and hopping-mice activity decreases along } \\
\text { an environmental (habitat) gradient that exists from } \\
\text { west to east (detectable in swales, but not on dunes), } \\
\text { but dingo and hopping-mice activity remains constant } \\
\text { (on both dunes and swales) on north-south running } \\
\text { transects }\end{array}$ \\
\hline & $\begin{array}{l}\text { Is hopping-mice PTI lower closer to waterpoints in } \\
\text { dingo-baited areas and higher closer to } \\
\text { waterpoints in unbaited areas? }\end{array}$ & & $\begin{array}{l}\text { Overall mean dingo and hopping-mice PTI } \\
\text { values at sand plots established at various } \\
\text { distances away from waterpoints }\end{array}$ & $\begin{array}{l}\text { Dingo and hopping-mice PTI similarly consistent at } \\
\text { various distances away from waterpoints, in both } \\
\text { baited and unbaited areas }\end{array}$ \\
\hline & $\begin{array}{l}\text { Do single-survey studies show hopping-mice PTI } \\
\text { to be positively correlated with dingo PTI at fine } \\
\text { scales (i.e. at the sand plot level)? }\end{array}$ & & $\begin{array}{l}\text { Dingo and hopping-mice PTI values at each } \\
\text { sand plot in baited and unbaited areas during } \\
\text { each survey }\end{array}$ & $\begin{array}{l}\text { Fine-scale relationships between dingoes and } \\
\text { hopping-mice can be either positive (once only in the } \\
\text { baited area), negative (twice only in the unbaited area) } \\
\text { or typically neutral ( } 15 \text { of } 16 \text { surveys in the baited } \\
\text { area; } 14 \text { of } 16 \text { surveys in the unbaited area) when only } \\
\text { individual surveys are considered in isolation }\end{array}$ \\
\hline \multirow[t]{4}{*}{ Predatory relationships } & How common are hopping-mice in dingo scats? & $\begin{array}{l}\text { Systematic collection of dingo scats from } 5 \\
\text { fenced waterpoints in baited and unbaited } \\
\text { areas during most PTI surveys }\end{array}$ & $\begin{array}{l}\text { Records of prey remains found in } 2571 \text { dingo } \\
\text { scats in dingo-baited and unbaited areas }\end{array}$ & $\begin{array}{l}\text { Percent occurrence of hopping-mice in dingo scats } \\
\text { ranged between } 2 \% \text { and } 64 \% \text { during different surveys } \\
\text { (11\% occurrence overall) }\end{array}$ \\
\hline & $\begin{array}{l}\text { Are hopping-mice always consumed along with } \\
\text { other mammalian prey? }\end{array}$ & & & $\begin{array}{l}\text { Of the } 285 \text { scats containing hopping-mice, } 71 \%(\mathrm{~N}= \\
\text { 203) contained hopping-mice as the sole mammalian } \\
\text { prey item }\end{array}$ \\
\hline & $\begin{array}{l}\text { Do hopping-mice feature in dingo diets } \\
\text { consistently, or only when preferred dingo prey } \\
\text { (rabbits) are unavailable? }\end{array}$ & & & $\begin{array}{l}\text { There is an inverse relationship between rabbits and } \\
\text { hopping-mice in dingo scats (i.e. substitution of rabbit } \\
\text { for hopping-mice when rabbits are unavailable) }\end{array}$ \\
\hline & $\begin{array}{l}\text { Are hopping-mice consumed by dingoes in } \\
\text { proportion to their availability? }\end{array}$ & & $\begin{array}{l}\text { Records of prey remains found in } 2571 \text { dingo } \\
\text { scats, and hopping-mice PTI trends in both } \\
\text { dingo-baited and unbaited areas }\end{array}$ & $\begin{array}{l}\text { The percent occurrence of hopping-mice in scats } \\
\text { increases as hopping-mice PTI decreases }\end{array}$ \\
\hline
\end{tabular}


Table 3

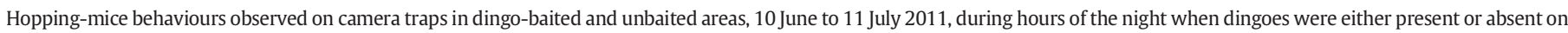
camera.

\begin{tabular}{|c|c|c|c|c|c|c|c|}
\hline & & \multicolumn{6}{|c|}{ Hopping-mice behaviours observed (\%) } \\
\hline & & Feeding & Sitting & Walking & Running & Interacting & Foraging \\
\hline \multirow[t]{2}{*}{ Unbaited } & Dingoes absent & 4.7 & 42.7 & 20.0 & 20.0 & 1.3 & 67.3 \\
\hline & Dingoes present & 9.8 & 39.3 & 17.2 & 24.6 & 0.0 & 66.4 \\
\hline \multirow[t]{2}{*}{ Baited } & Dingoes absent & 53.5 & 16.1 & 12.0 & 12.8 & 0.6 & 81.6 \\
\hline & Dingoes present & 51.1 & 14.1 & 12.8 & 13.8 & 3.7 & 78.1 \\
\hline
\end{tabular}

df 26, $\mathrm{p}=0.1400$ ) between dingo and hopping-mice activity (Fig. S3). There was also no linear relationship $(r=-0.2596, \mathrm{df}=26, \mathrm{p}=$ 0.1822 ) between dingo activity and the number of foraging hoppingmice observed per camera (Fig. S3). Hopping-mice behaviour was almost identical in hours when dingoes were either absent or present on camera, in both Finlay and Coonee (Table 3). Hopping-mice were also more active on sand dunes than they were on swales, at all times (Table S3). Habitat selection analyses demonstrated that all collared dingoes selected sand dunes over swales during the night (Fig. 1). In other words, dingoes preferentially selected the habitat where hopping-mice were active, during the time that hopping-mice were active (see also Fig. S2).

\subsection{Spatial and numerical relationships between dingoes and hopping-} mice

Dingo and hopping-mice PTI trends were near-identical between treatments regardless of whether or not sampling occurred on dunes or swales (Figs. 2, 3 and S4; see also Allen et al., 2014a). In the unbaited area (Coonee), overall mean hopping-mice PTI declined along an environmental gradient from west to east (Fig. 3, Table S4), or in other words, from the centre of the desert towards the edge $(r=-0.3378$, df $24, \mathrm{p}=0.0986$ ). This pattern was not observed from south to north, when sampling remained only within the centre of the desert $(\mathrm{r}=-0.1475$, df $24, \mathrm{p}=0.4817)$. A similar pattern occurred for dingoes (west to east: $\mathrm{r}=-0.4254$, df $24, \mathrm{p}=0.0340$; south to north: $r=-0.1219$, df $24, p=0.5615$ ), indicating that fewer tracks of both species are observed the further away from the centre of the desert that sampling occurred (Figs. 3 and S4, Table S4). Overall mean hopping-mice PTI was essentially equal across varying distances from water in Finlay $(r=-0.2133$, df $8, p=0.5816)$, but fluctuated somewhat in Coonee ( $\mathrm{r}=0.5595$, df $8, \mathrm{p}=0.1172$; Fig. 4). Overall mean dingo PTI was essentially equal across varying distances from water in both treatments (Finlay, baited: $\mathrm{r}=-0.1981$, $\mathrm{df} 8, \mathrm{p}=0.6095$; Coonee, unbaited: $r=-0.5296$, df $8, p=0.1426$ ). Thus, spatial patterns in the distribution

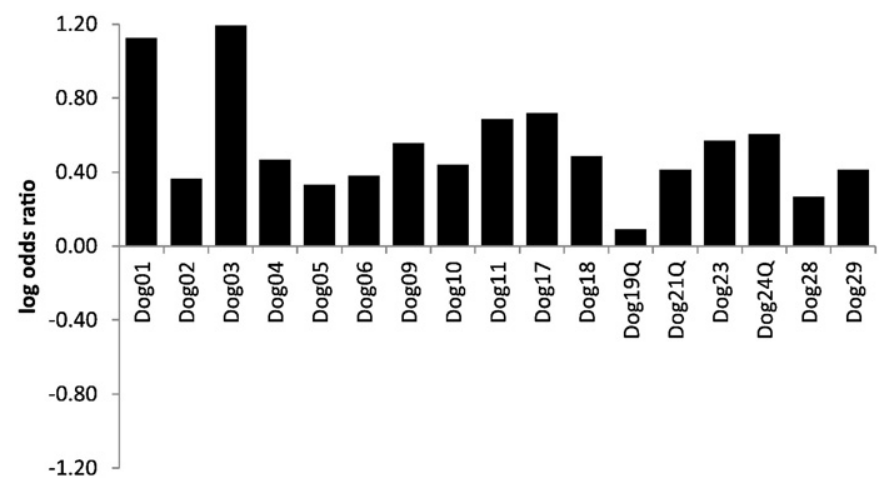

Fig. 1. Habitat selection patterns between 18:00 pm and 06:00 am for 17 dingoes at Quinyambie Station, 2008-2012. Positive values indicate selection of sand dunes over swales. of hopping-mice PTI at different distances away from water were independent of dingo PTI at different distances away from water, and were also largely unrelated to the presence of a waterpoint per se (Fig. 4). Fine-scale spatial relationships between dingoes and hopping-mice were typically neutral and non-significant during individual surveys (Table 4).

\subsection{Predatory relationships between dingoes and hopping-mice}

Besides rabbits and hopping-mice, no other vertebrate occurred commonly in dingo scats at the site (Table S2; Allen and Leung, 2012; Allen and Leung, 2014). Rabbits were commonly detected in dingo scats at most times, and should be considered primary prey for dingoes at the site; hopping-mice might be considered secondary prey. Hopping-mice were consumed by dingoes more often in flush periods than drought periods in both Finlay $(t=-1.8887, \mathrm{df} 7, \mathrm{p}=0.0504)$ and Coonee $(\mathrm{t}=-2.7881, \mathrm{df} 8, \mathrm{p}=0.0118)$. Rabbits were consumed by dingoes less often in flush periods than drought periods in both Finlay $(t=3.2562$, df $10, p=0.0043)$ and Coonee $(t=6.2985$, df $9, p=$ 0.0001 ). Thus, there was a demonstrable negative relationship between the percentage of rabbit and hopping-mice remains in dingo scats at both Finlay $(r=-0.6740$, df $13, p=0.0082)$ and Coonee $(r=$ -0.7842 , df $13, p=0.0009$ ), indicating substitution of rabbits with hopping-mice by dingoes independent of treatment (Fig. 5; see also Allen and Leung, 2014). Comparing hopping-mice population trends with their percent occurrence in dingo scats showed that during 2009 (at the climax of the drought), the occurrence of hopping-mice in dingo scats increased as hopping-mice populations were declining (Fig. 6).

\section{Discussion}

Drought, flood, fire, habitat availability, provision of artificial water points, competition from livestock and invasive species, predation, and the lethal control of top-predators have each been proposed as biotic and abiotic drivers of threatened fauna populations, including hopping-mice, in arid Australian ecosystems (e.g. Burbidge and McKenzie, 1989; Burbidge et al., 2008; Doherty et al., 2015; Woinarski et al., 2015). Despite many ultimate and proximate causes, the general mechanism of fauna decline is thought to be a reduction of food and/or cover followed by predation (Allen, 2011a; Lawes et al., 2015; Woinarski et al., 2015). In support of this view, our results show that geological gradients of habitat (sand dune) availability most strongly influences local hopping-mice distribution, food availability primarily limits their abundance, and dingo predation has the capacity to regulate or suppress hopping-mice populations during drought (Table 2). Sand dune habitat appears critical for sustaining hopping-mice populations given that their presence declined as the height and density of sand dunes likewise declined (Fig. 3; see also Moseby et al., 1999). Hopping-mice population trends fluctuated independent of dingo control (Fig. 2; see also Allen et al., 2014a) and were not influenced to a great extent by livestock grazing or the presence of artificial waterpoints (Fig. 4), but responded most strongly to rainfall or the lack thereof. Prey switching by dingoes from rabbits to hopping-mice as hopping-mice declined (Fig. 5) further 
Finlay
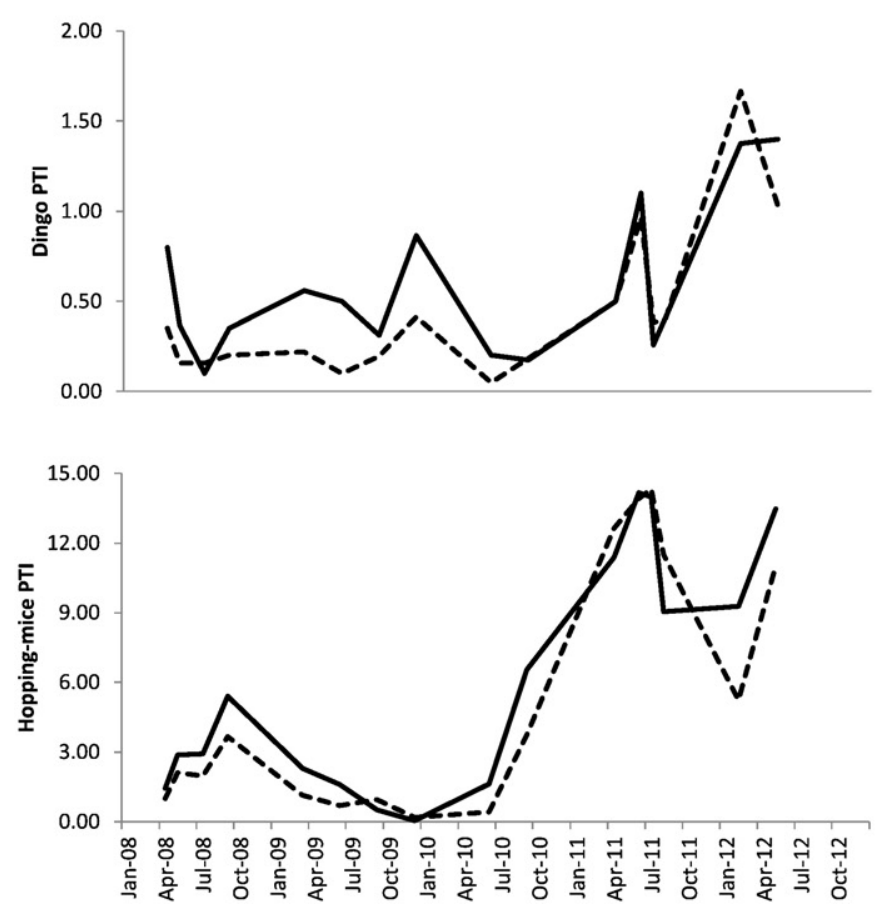

Coonee
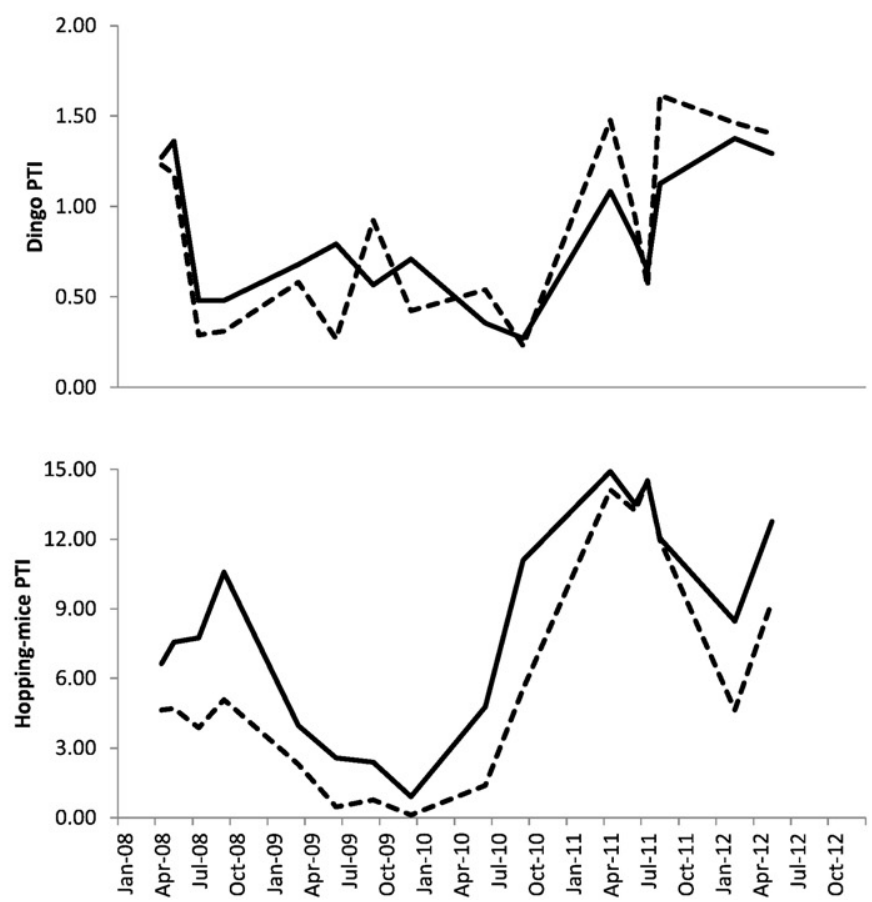

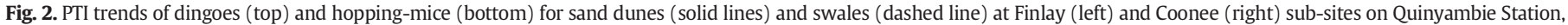
2008-2012, indicating that PTI trends for both species fluctuate independently of dingo control and habitat type.

indicates that during times of rainfall shortage or drought, persistence of hopping-mice populations might be threatened by dingo predation (Fig. 6; see also Newsome and Corbett, 1975; Sinclair et al., 1998; Allen and Leung, 2012).

Regarding Hypotheses 1 and 2, positive relationships between dingoes and hopping-mice were not commonly observed across small spatial and temporal scales (Table 4, Fig. S3), but were apparent over longer timeframes and larger scales (Fig. 2). However, this relationship did not arise as a result of a complicated cascading process of indirect protection of hopping-mice from mesopredator predation by dingoes (Allen et al., 2013a; Allen et al., 2014a). Rather, the more parsimonious explanation for this positive relationship is that dingo population abundance is greater in the presence of their two most preferred prey (Allen and Leung, 2012; see also White, 2013). The presence of dingoes did not influence the foraging behaviour of hopping-mice (Table 3, Plate S3), suggesting that hopping-mice perceive predation as a relatively constant threat, regardless of predator identity. The presence of dingoes was experimentally demonstrated to not have changed mesopredator abundance during the study (Allen et al., 2013a). However, assuming the presence of dingoes actually does reduce the risk of mesopredator

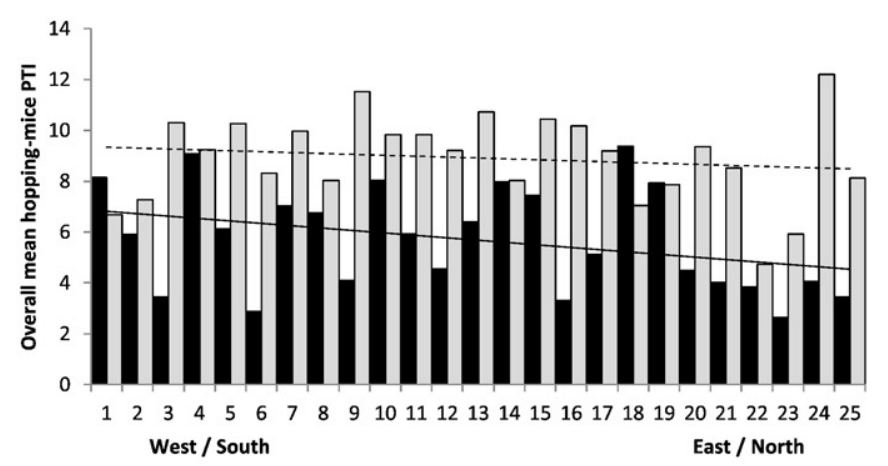

predation to hopping-mice, our results suggest that hopping-mice do not recognise this change in predation risk or change their behaviour accordingly (Table 3). Rather, it appears that hopping-mice fear predation by dingoes just as much as they fear predation by foxes or cats, which have each been shown to pose similar risks to hopping-mice (Coutts-Smith et al., 2007; Allen and Fleming, 2012). Differences between our results and those of previous studies are likely related to differences in experimental designs, with all previous studies based on small spatiotemporal scales and/or correlative study designs, in contrast to our large spatiotemporal scale and comprehensive experimental approaches (Allen et al., 2013b; Allen et al., 2017).

Previous studies on relationships between dingoes and hoppingmice at the site have relied on comparisons of 'dingo common or unbaited' and 'dingo uncommon or baited' areas on either side of the dingo barrier fence (e.g. Letnic et al., 2009; Letnic and Koch, 2010; Gordon et al., 2015). Although the general patterns observed in such studies conform nicely to (and contributed to the development of) the five hypotheses described above, their inferential ability is limited by previously untested plausible alternative hypotheses that may also explain the easily-observed and obvious cross-fence differences in dingo

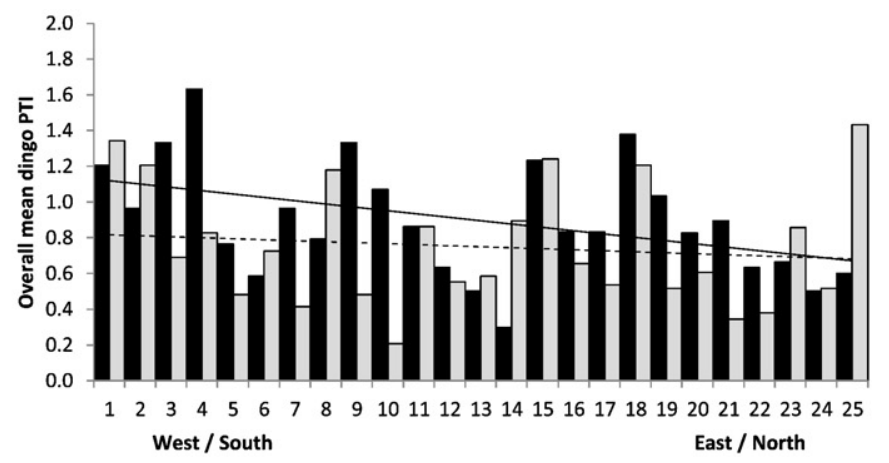

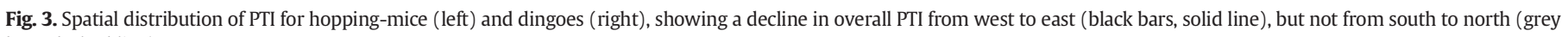
bars, dashed line). 


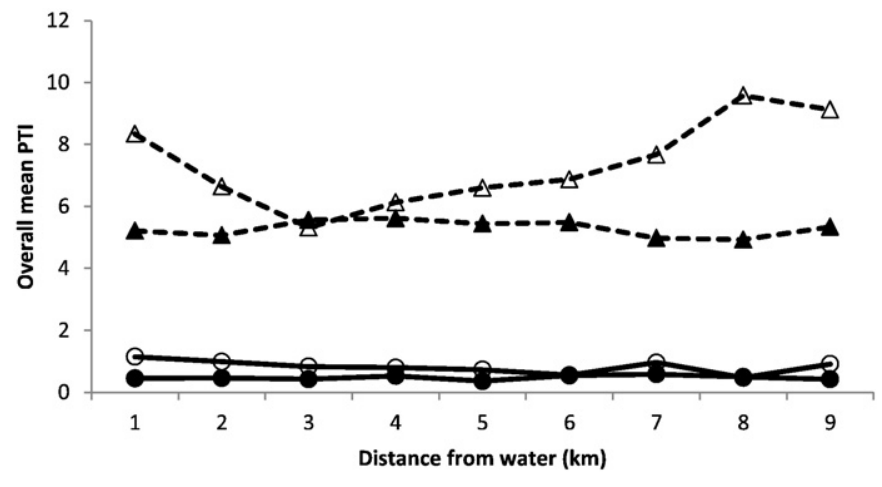

Fig. 4. The relationship between overall PTI and distance to water for dingoes (circles, solid lines) and hopping mice (triangles, dashed lines) at Finlay (solid marks) and Coonee (hollow marks) on Quinyambie Station, 2008-2012, indicating that PTI trends for both dingoes and hopping-mice fluctuate independently of distance to water.

and hopping-mice abundance. Cross-fence differences in contemporary and historical grazing pressure is foremost amongst these alternative hypotheses (Allen, 2011a), although differences in landform and other hydrological and geological processes have also been identified (Newsome et al., 2001). Our study addresses and overcomes these issues by assessing predator-prey relationships (on the same side of the fence) in places with measured livestock grazing differences with similar grazing histories and inclusive of an explicit assessment of geological gradients from the centre of the desert to its edge. Hence, with regard to Hypothesis 3, our results indicate that the abundance of hopping-mice in the eastern parts of the Strzelecki Desert (i.e. 'dingo uncommon or baited' areas assessed in previous studies) are lower there than in the western parts of the desert (i.e. 'dingo common or unbaited' areas in previous studies) not because dingoes are less abundant or subject to lethal control, but because there is less available habitat (sand dunes) for hopping-mice in the east (Fig. 3), as originally proposed by Newsome et al. (2001) and later reinforced in Allen et al. (2014a). Thus, the bottomup effect of the environmental gradient better explains predator and prey distribution and abundance at the site than does the hypothesised lethal control-induced absence of dingoes.

Although dingo control temporarily reduced dingo PTI at times (Allen et al., 2013a), dingo, mesopredator and hopping-mice populations fluctuated independently of contemporary poison baiting practices over time (Fig. 2; see also Allen et al., 2014a). Thus, Hypothesis 4 was not supported by our data. For similar reasons to those just described, this difference between our results and those of previous studies is likely related to the experimental design constraints of previous studies. No previous study conducted at the site has attempted to measure the direct effect of dingo control on dingoes (Allen et al., 2013b; see also Allen, 2015b), but have instead simply assumed that the act of baiting automatically and consistently produces some large negative but unmeasured numerical and/or functional effect on dingoes. By simultaneously measuring the direct and indirect effects of baiting on dingoes and hopping-mice before and after baiting in paired baited and unbaited areas over several years, and controlling for other potentially influential factors (e.g. livestock grazing and environmental

Table 4

The frequency of demonstrably positive and negative (where $\mathrm{p} \leq 0.05$ ) or neutral (where $\mathrm{p}$ $\geq 0.05$ ) fine-scale relationships between dingoes and hopping-mice observed during 16 individual PTI surveys on Quinyambie, 2008-2012 ( ${ }^{*} r^{2}=0.18 ;{ }^{\wedge} r^{2}=0.09$ and 0.16$)$.

\begin{tabular}{lll}
\hline & Finlay (baited) & Coonee (unbaited) \\
\hline Positive relationship & $1^{*}$ & 0 \\
Negative relationship & 0 & $2^{\wedge}$ \\
Neutral/no relationship & 15 & 14 \\
\hline
\end{tabular}

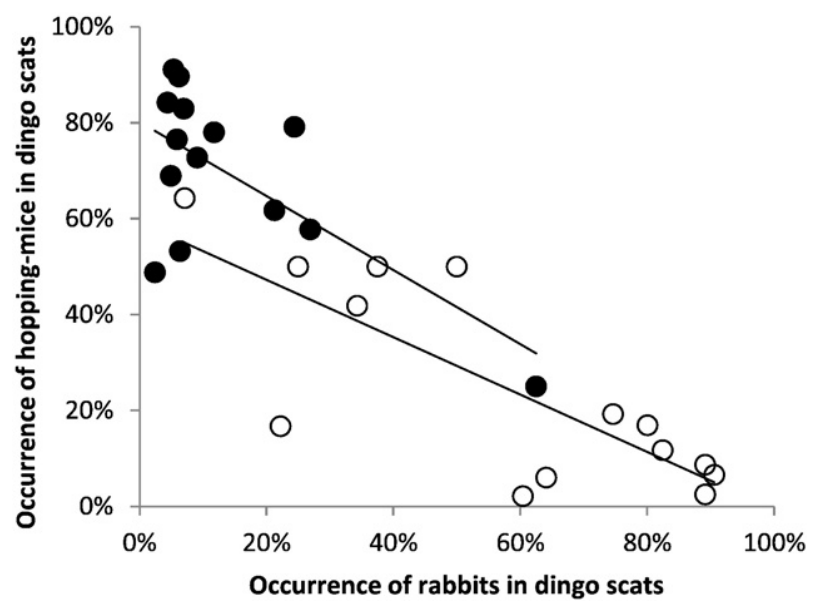

Fig. 5. Relationship between the occurrence of rabbits and hopping-mice in dingo scats in Finlay (solid marks) and Coonee (hollow marks) at Quinyambie Station, 2008-2012, showing evidence of substitution of rabbits for hopping-mice by dingoes at both sub-sites.

gradients), we demonstrate that contemporary dingo control practices do not reduce the overall abundance of dingoes, increase the overall abundances of mesopredators, or reduce the overall abundance of hopping-mice (Fig. 2; see also Allen et al., 2013a; Allen et al., 2014a). But with respect to Hypothesis 5, do dingoes threaten hopping-mice or not?

Our results also strongly indicate that dingo predation can threaten dusky hopping-mice populations under drought conditions, but not at other times. Dingoes were most active in the same sand dune habitat as hopping-mice (Table S3) and all collared dingoes selectively utilised this habitat type during night times when hopping-mice were active (Fig. 1). Hopping-mice remains were found in dingo scats during every scat survey conducted at either sub-site, occurring in up to $64 \%$ of dingo scats at times (Table S2; see also Allen and Leung, 2012; Allen and Leung, 2014). Hopping-mice occurrence in dingo scats increased as rabbit occurrence in dingo scats decreased, and vice versa (Fig. 5), indicating that dingoes substitute rabbits for hopping-mice. Of primary concern, however, is that the occurrence of hopping-mice in dingo scats increased (at both sub-sites) as hopping-mice abundance decreased towards the climax of the drought (Fig. 6), coinciding with near undetectably-low levels of hopping-mice activity. In other words, our data show that dingoes and hopping-mice are most active in the same places at the same times, dingoes routinely prey on hoppingmice, and that dingo consumption of hopping-mice increased as hopping-mice populations were dwindling. These data suggest that prolonged drought exacerbates the extinction risk to hopping-mice populations by lengthening the time that low-density hopping-mice populations are exposed to dingo predation and other stochastic effects (Letnic and Dickman, 2006, 2010). That climate change is likely to increase the frequency and severity of droughts (Moise and Hudson, 2008; McCluney et al., 2012) suggests that hopping-mice may become more susceptible to predation by dingoes and other predators in the future. Dingo predation alone may be unable to drive hopping-mice to extinction. However, in combination with other influences including predation by additional predators, competition with other herbivores, and land use change or stochastic effects (McKenzie et al., 2007; Fensham and Fairfax, 2008), dingo predation may at least be 'the straw that breaks the camel's back' (Allen, 2011a).

Seven of the 10 most frequently occurring prey species in dingo scats from arid areas weigh $<250 \mathrm{~g}$ (Corbett, 2001), and prolonged, droughtinduced prey suppression by dingoes has previously been shown to limit prey populations in these areas (Newsome et al., 1989). Newsome et al. (1975) and Sinclair et al. (1998) showed that dingoes can suppress rodent populations (including spinifex hopping-mice, Notomys alexis; $35 \mathrm{~g}$ ), restricting their geographic range and density to 

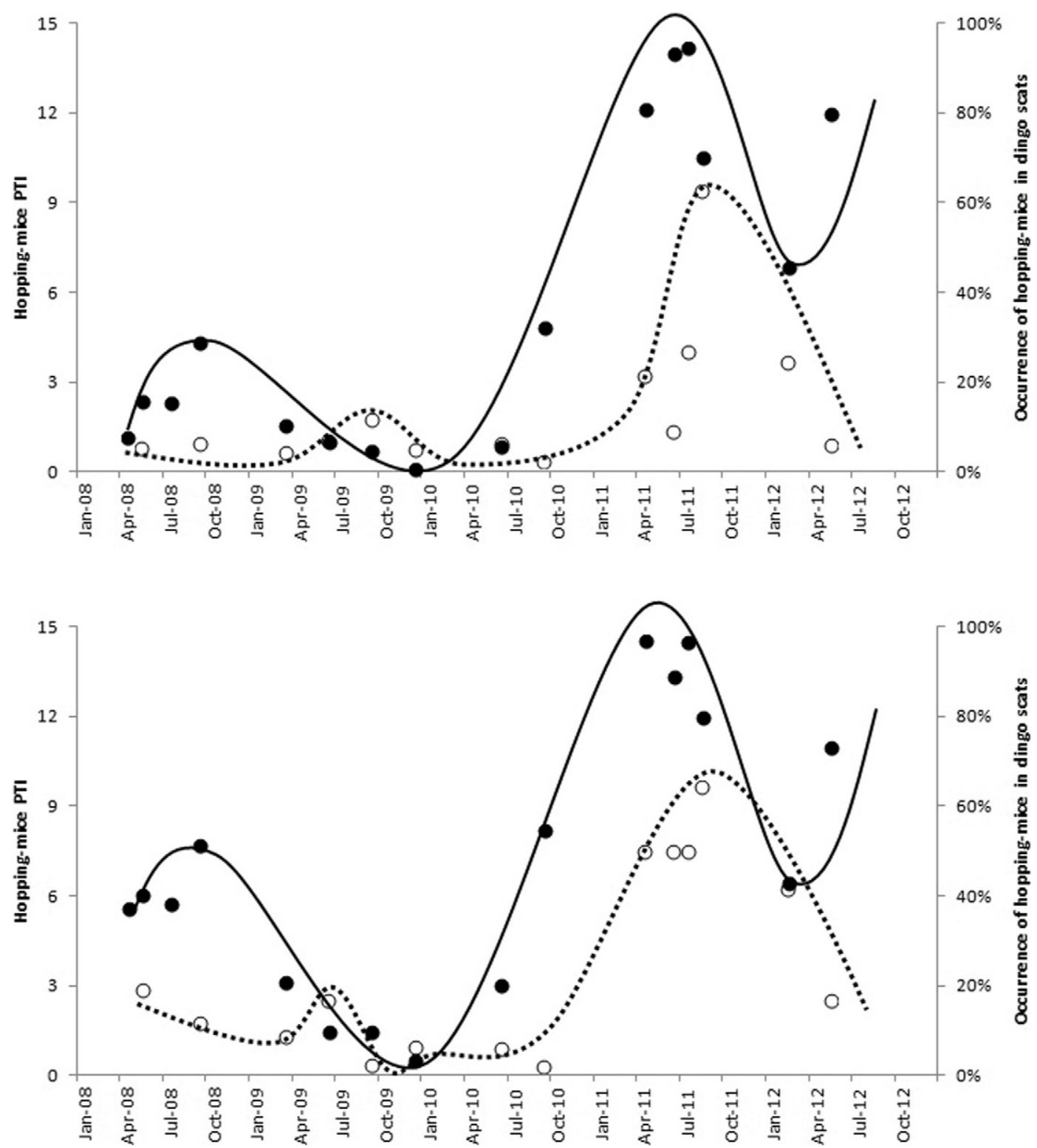

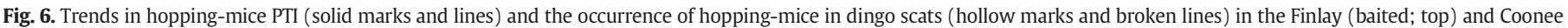
(unbaited; bottom) paddocks of Quinyambie Station, 2008-2012, showing increasing consumption of hopping-mice by dingoes at the climax of the drought in mid-2009.

the point where additional stochastic effects (such as drought, wildfire or disease) may result in localised rodent extinctions. The mechanism by which dingoes switch between prey was described as 'alternation of predation' by Corbett and Newsome (1987), where dingoes in desert areas switch between rodents and rabbits depending on their relative availability and the prevailing environmental conditions. Later findings by Newsome (2011); but see also Newsome et al. (2013) concur, demonstrating an elevated risk of decline to desert mice (Pseudomys desertor; $25 \mathrm{~g}$ ) where dingoes were provided alternative food subsidies. Pavey et al. (2008) likewise report that rodents (including N. alexis) were the main prey for dingoes when available, occurring in over $70 \%$ of dingo scats, or at a rate of two rodents per dingo per day. In accord with these studies, Allen and Leung (2012) reported that hoppingmice may also be suppressed by dingoes, potentially consuming up to 20 hopping-mice per dingo per day at times. Thus, dingo predation is known or expected to threaten rodent populations when rodents are in low densities and other prey are unavailable, and when rodents are a supplementary prey source to other high-density primary prey (i.e. hyperpredation).

\section{Conclusions}

Our study supports the general view that reductions in food and cover followed by predation (by dingoes in this case) can lead to declines of small mammals in Australia (Allen, 2011a; Lawes et al., 2015; Woinarski et al., 2015), and highlights the relative influence of multiple environmental (bottom-up) and human (top-down) effects on predator-prey interactions. These results have important implications for land managers and policy-makers responsible for the management of predators and prey. Unfavourable drought conditions are predicted to become more frequent and intense in the future, which should encourage temperance and caution when considering the utility of generalist predators (such as dingoes) as biodiversity conservation tools for recovering small mammals, especially in cases where the small mammals of concern comprise an important component of the top-predators' diets (Salo et al., 2010). Efforts to conserve threatened fauna by enhancing top-predator populations must explicitly consider the possibility that predicted climate changes may alter historically-sustainable predatorprey relationships and tip the balance in favour of predators in some 
circumstances. Bottom-up (environmental) effects were more influential in shaping predator-prey relationships than were top-down (human) effects, which further suggests that fauna restoration efforts will likely have greater prospects for success by improving the food and cover resources available to prey rather than by attempting to alter predator abundances. Our study also highlights how local topdown management actions can have a relatively minor influence on systems strongly influenced by global bottom-up processes.

\section{Acknowledgements}

This study would not have been possible without the generous support of S. Kidman and Co. cattle company and Mutoroo Pastoral Company, where Greg Campbell, Paul Jonas and Greg Conners granted access to the site. The work was administered by the South Australian Arid Lands Natural Resources Management Board, the Invasive Animals Cooperative Research Centre, and the New South Wales Department of Primary Industries, with financial support obtained from state and federal government funding programs (including Natural Heritage Trust, and Caring for Our Country). Heather Miller, Joseph Allen, Lee Allen, Simon Cobb and Stuart Boyd-Law assisted in the capture of dingoes and collar retrieval. Barbara Triggs (Dead Finish) analysed prey remains in dingo scats. Emma Allen and Simon Humphries assisted with camera trap deployment and retrieval. Stephanie Wende assisted with data entry. Helpful comments on earlier drafts of components of the work were provided by Lee Allen, Peter Bird, Matt Gentle, John Read and Joe Scanlan. The study was conducted in accordance with approvals granted by the South Australian Department of Environment and Heritage's Wildlife Ethics Committee (WEC 16/2008-M2) and the Australian Pesticides and Veterinary Medicines Authority (PER8904).

\section{Appendix A. Supplementary methods and results}

Supplementary data to this article can be found online at http://dx. doi.org/10.1016/j.scitotenv.2017.08.051.

\section{References}

Allen, B.L., 2010. Skin and bone: observations of dingo scavenging during a chronic food shortage. Austr. Mammal. 32, 1-2.

Allen, B.L., 2011a. A comment on the distribution of historical and contemporary livestock grazing across Australia: implications for using dingoes for biodiversity conservation. Ecol. Manag. Restor. 12 (1), 26-30.

Allen, B.L., 2011b. Efficacy of Para-aminopropiophenone (PAPP) to Control Dingoes (Canis lupus spp.) in the Strzelecki Desert of South Australia: Quinyambie Field Trial. Melbourne, Animal Control Technologies Australia.

Allen, B.L., 2012a. Do desert dingoes drink daily? Visitation rates at remote waterpoints in the Strzelecki Desert. Aust. Mammal. 34 (2), 251-256.

Allen, B.L., 2012b. The effect of lethal control on the conservation values of Canis lupus dingo. In: Maia, A.P., Crussi, H.F. (Eds.), Wolves: Biology, Conservation, and management. New York, Nova Publishers, pp. 79-108.

Allen, B.L., 2012c. Scat happens: spatiotemporal fluctuation in dingo scat collection rates. Austr. J. Zool. 60 (2), 137-140.

Allen, B.L., 2015a. More buck for less bang: reconciling competing wildlife management interests in agricultural food webs. Food Webs 2, 1-9.

Allen, B.L., 2015b. Top-predator control-induced trophic cascades: an alternative hypothesis to the conclusion of Colman et al. (2014). Proc. R. Soc. B 282 (1799), 1-3.

Allen, L.R., Engeman, R.M., 2014. Evaluating and validating abundance monitoring methods in the absence of populations of known size: review and application to a passive tracking index. Environ. Sci. Pollut. Res. 22, 2907-2915.

Allen, B.L., Fleming, P.J.S., 2012. Reintroducing the dingo: the risk of dingo predation to threatened vertebrates of western New South Wales. Wildl. Res. 39 (1), 35-50.

Allen, B.L., Leung, L.K.-P., 2012. Assessing predation risk to threatened fauna from their prevalence in predator scats: dingoes and rodents in arid Australia. PLoS One 7 (5), e36426.

Allen, B.L., Leung, K.-P., 2014. The (non)effects of lethal population control on the diet of Australian dingoes. PLoS One 9 (9), e108251.

Allen, L., Engeman, R., Krupa, H., 1996. Evaluation of three relative abundance indices for assessing dingo populations. Wildl. Res. 23 (2), 197-206.

Allen, B.L., Read, J.L., Medlin, G., 2011. Additional records of small mammals in northern South Australia. Aust. Mammal. 33, 68-72.

Allen, B.L., Allen, L.R., Engeman, R.M., Leung, L.K.-P., 2013a. Intraguild relationships between sympatric predators exposed to lethal control: predator manipulation experiments. Front. Zool. 10, 39.
Allen, B.L., Fleming, P.J.S., Allen, L.R., Engeman, R.M., Ballard, G., Leung, L.K.-P., 2013b. As clear as mud: a critical review of evidence for the ecological roles of Australian dingoes. Biol. Conserv. 159, 158-174.

Allen, B.L., Allen, L.R., Engeman, R.M., Leung, L.K.-P., 2014a. Sympatric prey responses to lethal top-predator control: predator manipulation experiments. Front. Zool. 11, 56

Allen, B.L., Engeman, R.M., Leung, L.K.-P., 2014b. The short-term effects of a routine poisoning campaign on the movement behaviour and detectability of a social top-predator. Environ. Sci. Pollut. Res. 21 (3), 2178-2190.

Allen, B.L., Allen, L.R., Andrén, H., Ballard, G., Boitani, L., Engeman, R.M., Fleming, P.J.S., Ford, A.T., Haswell, P.M., Kowalczyk, R., Linnell, J.D.C., Mech, L., Parker, D.M., 2017. Can we save large carnivores without losing large carnivore science? Food Webs $12,64-75$.

Blaum, N., Engeman, R.M., Wasiolka, B., Rossmanith, E., 2008. Indexing small mammalian carnivores in the southern Kalahari, South Africa. Wildl. Res. 35 (1), 72-79.

Brunner, H., Coman, B.J., 1974. The Identification of Mammalian Hair. Melbourne, Inkata Press.

Brunner, H., Triggs, B., Ecobyte Pty Ltd, 2002. Hair ID: An Interactive Tool for Identifying Australian Mammalian Hair. CSIRO Publishing, Collingwood, VIC

Burbidge, A.A., McKenzie, N.L., 1989. Patterns in the modern decline of Western Australia's vertebrate fauna: causes and conservation implications. Biol. Conserv. 50, 143-198.

Burbidge, A.A., McKenzie, N.L., Brennan, KE.C. Woinarski, J.C. Z, Dickman, C.R., Baynes, A Gordon, G., Menkhorst, P.W., Robinson, A.C., 2008. Conservation status and biogeography of Australia's terrestrial mammals. Aust. J. Zool. 56, 411-422.

Claridge, A.W., Cunningham, R.B., Catling, P.C., Reid, A.M., 2010. Trends in the activity levels of forest-dwelling vertebrate fauna against a background of intensive baiting for foxes. For. Ecol. Manag. 260 (5), 822-832.

Corbett, L.K., 2001. The dingo in Australia and Asia. 2 edn. J.B. Books, South Australia: Marleston.

Corbett, L., Newsome, A.E., 1987. The feeding ecology of the dingo III. Dietary relationships with widely fluctuating prey populations in arid Australia: an hypothesis of alternation of predation. Oecologia 74, 215-227.

Coutts-Smith, A.J., Mahon, P.S., Letnic, M., Downey, P.O., 2007. The Threat Posed by Pest Animals to Biodiversity in New South Wales. Invasive Animals Cooperative Research Centre, Canberra.

Cupples, J.B., Crowther, M.S., Story, G., Letnic, M., 2011. Dietary overlap and prey selectivity among sympatric carnivores: could dingoes suppress foxes through competition for prey? J. Mammal. 92 (3), 590-600.

Dickman, C.R., Mahon, P.S., Masters, P., Gibson, D.F., 1999. Long-term dynamics of rodent populations in arid Australia: the influence of rainfall. Wildl. Res. 26, 389-403.

Doherty, T.S., Dickman, C.R., Nimmo, D.G., Ritchie, E.G., 2015. Multiple threats, or multiplying the threats? Interactions between invasive predators and other ecological disturbances. Biol. Conserv. 190, 60-68.

Eldridge, S.R., Bird, P.L., Brook, A., Campbell, G., Miller, H.A., Read, J.L., Allen, B.L., 2016. The Effect of Wild Dog Control on Cattle Production and Biodiversity in the South Australian Arid Zone: Final Report. South Australian Arid Lands Natural Resources Management Board, Port Augusta, South Australia.

Engeman, R., 2005. Indexing principles and a widely applicable paradigm for indexing animal populations. Wildl. Res. 32 (3), 202-210.

Engeman, R., Allen, L., 2000. Overview of a passive tracking index for monitoring wild canids and associated species. Integr. Pest Manag. Rev. 5, 197-203.

Engeman, R., Evangelista, P., 2006. Investigating the feasibility of a tracking index for monitoring wildlife in the Lower Omo Valley, Ethiopia. Afr. J. Ecol. 45, 184-188.

Engeman, R.M., Allen, L.R., Zerbe, G.O., 1998. Variance estimate for the activity index of Allen et al. Wildl. Res. 25 (6), 643-648.

Estes, J.A., Terborgh, J., Brashares, J.S., Power, M.E., Berger, J., Bond, W.J., Carpenter, S.R., Essington, T.E., Holt, R.D., Jackson, J.B.C., Marquis, R.J., Oksanen, L., Oksanen, T., Paine, R.T., Pikitch, E.K., Ripple, W.J., Sandin, S.A., Scheffer, M., Schoener, T.W., Shurin, J.B., Sinclair, A.R.E., Soulé, M.E., Virtanen, R., Wardle, D.A., 2011. Trophic downgrading of planet earth. Science 333, 301-306.

Estes, J., Crooks, K., Holt, R.D., 2013. Ecological role of predators. Encyclopedia of Biodiversity, Second edition 6. Waltham, Academic Press, pp. 229-249 (Ed. SA Levin).

Fensham, R.J., Fairfax, R.J., 2008. Water-remoteness for grazing relief in Australian aridlands. Biol. Conserv. 141, 1447-1460.

Finke, D.L., Denno, R.F., 2004. Predator diversity dampens trophic cascades. Nature 429 (6990), 407-410.

Fitzsimmons, K.E., 2007. Morphological variability in the linear dunefields of the Strzelecki and Tirari Deserts, Australia. Geomorphology 91 (1-2), 146-160.

Fleming, P.J.S., Allen, B.L., Ballard, G., 2012. Seven considerations about dingoes as biodiversity engineers: the socioecological niches of dogs in Australia. Aust. Mammal. 34 (1), 119-131.

Glen, A.S., Pennay, M., Dickman, C.R., Wintle, B.A., Firestone, K.B., 2011. Diets of sympatric native and introduced carnivores in the Barrington Tops, eastern Australia. Aust. Ecol. 36 (3), 290-296.

Gordon, C.E., Feit, A., Grüber, J., Letnic, M., 2015. Mesopredator suppression by an apex predator alleviates the risk of predation perceived by small prey. Proc. R. Soc. B 282, 1802.

Gordon, C.E., Eldridge, D.J., Ripple, W.J., Crowther, M.S., Moore, B.D., Letnic, M., 2017. Shrub encroachment is linked to extirpation of an apex predator. J. Anim. Ecol. 86 (1), 147-157

Haswell, P.M., Kusak, J., Hayward, M.W., 2017. Large carnivore impacts are context-dependent. Food Webs 12, 3-13.

Hayward, M.W., Marlow, N., 2014. Will dingoes really conserve wildlife and can our methods tell? J. Appl. Ecol. 51 (4), 835-838.

Hayward, M.W., Boitani, L., Burrows, N.D., Funston, P.J., Karanth, K.U., MacKenzie, D.I., Pollock, K.H., Yarnell, R.W., 2015. Ecologists need robust survey designs, sampling and analytical methods. J. Appl. Ecol. 52 (2), 286-290. 
Holmes, J.C., 1995. Population regulation: a dynamic complex of interactions. Wildl. Res. 22, 11-19.

Holt, R.D., Huxel, G.R., 2007. Alternative prey and the dynamics of intraguild predation: theoretical perspectives. Ecology 88 (11), 2706-2712.

Johnson, C., 2006. Australia's Mammal Extinctions: A 50,000 Year History. Melbourne, Cambridge University Press.

Kershaw, K.A., 1969. Quantitative and Dynamic Ecology. London, Edward Arnold Publishers.

Kinnaird, M.F., Sanderson, E.W., O'Brien, T.G., Wibisono, H.T., Woolmer, G., 2003. Deforestation trends in a tropical landscape and implications for endangered large mammals Conserv. Biol. 17 (1), 245-257.

Klare, U., Kamler, J.F., Macdonald, D.W., 2011. A comparison and critique of different scatanalysis methods for determining carnivore diet. Mammal Rev. 41 (4), 294-312.

Krebs, C.J., 2008. Ecology: The Experimental Analysis of Distribution and Abundance. 6 edn. San Francisco, Benjamin-Cummings Publishing.

Kutsche, F., Lay, B., 2003. Field Guide to the Plants of Outback South Australia. Adelaide, Department of Water, Land and Biodiversity Conservation, Government of South Australia.

Lawes, M.J., Fisher, D.O., Johnson, C.N., Blomberg, S.P., Frank, A.S.K., Fritz, S.A., McCallum, H., VanDerWal, J., Abbott, B.N., Legge, S., Letnic, M., Thomas, C.R., Thurgate, N., Fisher, A., Gordon, I.J., Kutt, A., 2015. Correlates of recent declines of rodents in northern and southern Australia: habitat structure is critical. PLoS One 10 (6), e0130626.

Lee, A.K., 1995. The action plan for Australian rodents. Australian Nature Conservation Agency, Canberra.

Letnic, M., Dickman, C.R., 2006. Boom means bust: interactions between the El Niño/ Southern Oscillation (ENSO), rainfall and the processes threatening mammal species in arid Australia. Biodivers. Conserv. 15, 3847-3880.

Letnic, M., Dickman, C.R., 2010. Resource pulses and mammalian dynamics: conceptual models for hummock grasslands and other Australian desert habitats. Biol. Rev. 85 (3), 501-521.

Letnic, M., Koch, F., 2010. Are dingoes a trophic regulator in arid Australia? A comparison of mammal communities on either side of the dingo fence. Austr. Ecol. 35 (2) (267175).

Letnic, M., Crowther, M., Koch, F., 2009. Does a top-predator provide an endangered rodent with refuge from a mesopredator? Anim. Conserv. 12 (4), 302-312.

Linnell, J.D.C., 2011. The relative importance of predators and people in structuring and conserving ecosystems. Conserv. Biol. 25 (3), 646-647.

Marshall, K.N., Hobbs, N.T., Cooper, D.J., 2013. Stream hydrology limits recovery of riparian ecosystems after wolf reintroduction. Proc. R. Soc. B 280, 1756.

Marshall, K.N., Cooper, D.J., Hobbs, N.T., 2014. Interactions among herbivory, climate, topography and plant age shape riparian willow dynamics in northern Yellowstone National Park, USA. J. Ecol. 102 (3), 667-677.

McCluney, K.E., Belnap, J., Collins, S.L., González, A.L., Hagen, E.M., Nathaniel, Holland J., Kotler, B.P., Maestre, F.T., Smith, S.D., Wolf, B.O., 2012. Shifting species interactions in terrestrial dryland ecosystems under altered water availability and climate change. Biol. Rev. 87 (3), 563-582

McKenzie, N.L., Burbidge, A.A., Baynes, A., Brereton, R.N., Dickman, C.R., Gordon, G., Gibson, L.A., Menkhorst, P.W., Robinson, A.C., Williams, M.R., Woinarski, J.C.Z., 2007. Analysis of factors implicated in the recent decline of Australia's mammal fauna. J. Biogeogr. 34 (4), 597-611.

Meek, P.D., Pittet, A., 2012. User-based design specifications for the ultimate camera trap for wildlife research. Wildl. Res. 39, 649-660.

Meek, P.D., Ballard, G., Fleming, P.J.S., 2012. An introduction to camera trapping for wildlife surveys in Australia. PestSmart Toolkit Publication. Invasive Animals Cooperative Research Centre, Canberra, Australia.

Moise, A.F., Hudson, D.A., 2008. Probabilistic predictions of climate change for Australia and southern Africa using the reliability ensemble average of IPCC CMIP3 model simulations. J. Geophys. Res. 113, D15113.

Moseby, K.E., Brandle, R., Adams, M., 1999. Distribution, habitat and conservation status of the rare dusky hopping-mouse, Notomys fuscus (Rodentia: Muridae). Wildl. Res. 26, 479-494.

Moseby, K.E., Owens, H., Brandle, R., Bice, J.K., Gates, J., 2006. Variation in population dynamics and movement patterns between two geographically isolated populations of the dusky hopping mouse (Notomys fuscus). Wildl. Res. 33, 223-232.

Newsome, T.M., 2011. Ecology of the Dingo (Canis lupus dingo) in the Tanami Desert in Relation to Human-resource Subsidies. The University of Sydney (PhD thesis).
Newsome, A.E., Corbett, L.K., 1975. Outbreaks of rodents in semi-arid and arid Australia: Causes, preventions, and evolutionary considerations. In 'Rodents in desert environments'. In: Prakash, I, Gosh, PK (Eds.), Dr. W. Junk: The Hague, The Netherlands.

Newsome, A.E., Parer, I., Catling, P.C., 1989. Prolonged prey suppression by carnivores: predator-removal experiments. Oecologia 78 (4), 458-467.

Newsome, A.E., Catling, P.C., Cooke, B.D., Smyth, R., 2001. Two ecological universes separated by the dingo barrier fence in semi-arid Australia: interactions between landscapes, herbivory and carnivory, with and without dingoes. Rangel. J. 23 (1), 71-98.

Newsome, T.M., Ballard, G., Dickman, C.R., Fleming, P.J.S., van de Ven, R., 2013. Home range, activity and sociality of a top predator, the dingo: a test of the resource dispersion hypothesis. Ecography 36 (8), 914-925.

Newsome, T.M., Ballard, G., Crowther, M.S., Dellinger, J.A., Fleming, P.J.S., Glen, A.S., Greenville, A.C., Johnson, C.N., Letnic, M., Moseby, K.E., Nimmo, D.G., Nelson, M.P., Read, J.L., Ripple, W.J., Ritchie, E.G., Shores, C.R., Wallach, A.D., Wirsing, A.J., Dickman, C.R., 2015. Resolving the value of the dingo in ecological restoration. Restor. Ecol. 23 (3), 201-208.

Nimmo, D.G., Watson, S.J., Forsyth, D.M., Bradshaw, C.J.A., 2015. Dingoes can help conserve wildlife and our methods can tell. J. Appl. Ecol. 52 (2), 281-285.

Pavey, C.R., Eldridge, S.R., Heywood, M., 2008. Population dynamics and prey selection of native and introduced predators during a rodent outbreak in arid Australia. J. Mammal. 89 (3), 674-683.

Petchey, O.L., McPhearson, P.T., Casey, T.M., Morin, P.J., 1999. Environmental warming alters food-web structure and ecosystem function. Nature 402 (6757), 69-72.

Peterson, R.O., Vucetich, J.A., Bump, J.M., Smith, D.W., 2014. Trophic cascades in a multicausal world: Isle Royale and Yellowstone. Annu. Rev. Ecol. Evol. Syst. 45, 325-345.

Ripple, W.J., Estes, J.A., Beschta, R.L., Wilmers, C.C., Ritchie, E.G., Hebblewhite, M., Berger, J., Elmhagen, B., Letnic, M., Nelson, M.P., Schmitz, O.J., Smith, D.W., Wallach, A.D., Wirsing, A.J., 2014. Status and ecological effects of the world's largest carnivores. Science 343, 151-163.

Ritchie, E.G., Elmhagen, B., Glen, A.S., Letnic, M., Ludwig, G., McDonald, R.A., 2012. Ecosystem restoration with teeth: what role for predators? Trends Ecol. Evol. 27 (5), 265-271.

Robin, L., Heinsohn, R., Joseph, L., 2009. Boom and Bust: Bird Stories for a Dry Country. CSIRO Publishing: Collingwood, Victoria, Australia.

Salo, P., Banks, P.B., Dickman, C.R., Korpimaki, E., 2010. Predator manipulation experiments: impacts on populations of terrestrial vertebrate prey. Ecol. Monogr. 80 (4), 531-546.

Sergio, F., Caro, T., Brown, D., Clucas, B., Hunter, J., Ketchum, J., McHugh, K., Hiraldo, F., 2008. Top predators as conservation tools: ecological rationale, assumptions, and efficacy. Annu. Rev. Ecol. Evol. Syst. 39, 1-19.

Sinclair, A.R.E., Pech, R.P., Dickman, C.R., Hik, D., Mahon, P., Newsome, A.E., 1998. Predicting the effects of predation on conservation of endangered prey. Conserv. Biol. 12 (3), 564-575.

Sinclair, A.R.E., Metzger, K.L., Fryxell, J.M., Packer, C., Byrom, A.E., Craft, M.E., Hampson, K., Lembo, T., Durant, S.M., Forrester, G.J., Bukombe, J., Mchetto, J., Dempewolf, J., Hilborn, R., Cleaveland, S., Nkwabi, A., Mosser, A., Mduma, S.A.R., 2013. Asynchronous food web pathways could buffer the response of Serengeti predators to El Niño Southern Oscillation. Ecol. Appl. 94 (5), 1123-1130.

Tylianakis, J.M., Didham, R.K., Bascompte, J., Wardle, D.A., 2008. Global change and species interactions in terrestrial ecosystems. Ecol. Lett. 11 (12), 1351-1363.

Van Dyck, S., Strahan, R., 2008. The Mammals of Australia. Third edn. Sydney, Reed New Holland.

West, P., 2008. Assessing Invasive Animals in Australia 2008. National Land and Water Resources Audit, The Invasive Animals Cooperative Research Centre, Canberra.

Whetton, P.H., Fowler, A.M., Haylock, M.R., Pittock, A.B., 1993. Implications of climate change due to the enhanced greenhouse effect on floods and droughts in Australia. Clim. Chang. 25 (3), 289-317.

White, T.C.R., 2013. Experimental and observational evidence reveals that predators in natural environments do not regulate their prey: they are passengers, not drivers. Acta Oecol. 53, 73-87.

Wikenros, C., Sand, H., Bergstrom, R., Liberg, O., Chapron, G., 2015. Response of moose hunters to predation following wolf return in Sweden. PLoS One 10 (4), e0119957.

Wilson, G.J., Delahay, R.J., 2001. A review of methods to estimate the abundance of terrestrial carnivores using field signs and observation. Wildl. Res. 28, 151-164.

Woinarski, J.C.Z., Burbidge, A.A., Harrison, P.L., 2015. Ongoing unraveling of a continental fauna: decline and extinction of Australian mammals since European settlement. Proc. Natl. Acad. Sci. 112 (15), 4531-4540. 